\title{
Revisiting the socio-educational model of second language acquisition in Turkish tertiary EFL context
}

\author{
Seden Eraldemir Tuyan* (iD) Ergun Serindag ${ }^{\text {b }}$ \\ ${ }^{a}$ Cag University, ELT Department, Mersin, 33800, Turkey \\ ${ }^{b}$ Cukurova University, School of Foreign Languages, YADYO, Adana, 01330, Turkey

\section{APA Citation:}

Eraldemir Tuyan, S., \& Serindag, E. (2019). Revisiting the socio-educational model of second language acquisition in Turkish tertiary EFL context. Journal of Language and Linguistic Studies, 15(2), 450-469.

Submission Date: 14/09/2018

Acceptance Date: $17 / 05 / 2019$

\begin{abstract}
The aim of this study is to analyze and determine the various socio-psychological orientations of undergraduate students in learning English as a Foreign Language (EFL) to have a comprehensive overview. The study was originally intended by the school administration to improve the quality of instruction and promote positive attitudes by understanding individual students, mainly in terms of their language learning motivation and attitudes towards learning English. The participants were 793 university prep-year students studying a one-year EFL program to complete their postsecondary education in an English-medium state university in Turkey. The data were collected using Attitude-Motivation Test Battery (AMTB) (adapted Turkish version, Gardner, 2004). The collected data were analyzed using SPSS 23 software firstly to be able to display the current situation regarding the 6 constructs measured by AMTB, mainly; integrativeness, attitudes toward the learning situation, motivation, language anxiety, instrumental orientation and parental encouragement levels of Turkish tertiary students in EFL learning by gender and level of proficiency. The results of this study identified that Turkish EFL learners at tertiary level showed relatively high levels of the qualities measured by the AMTB constructs and their sub-scales, except in attitudes toward English speaking people and anxiety. As an interesting finding, the participating students of the study were found to be often anxious in participating the English classes and using English, while female students felt more discomfort concerning these issues.
\end{abstract}

(C) 2019 JLLS and the Authors - Published by JLLS.

Keywords: attitudes towards EFL; EFL motivation; ELT in prep schools; Turkish AMTB; ELT in Turkey

\section{Introduction}

English is an international language and its significance has also been grasped very well in Turkey like in many other countries. Nevertheless, the results of a large-scale research into the teaching of English in state schools implemented by the British Council and Economic Policy Research Foundation of Turkey (TEPAV) in 2013 signaled for betterment in the area of English language teaching (ELT). The resultant Turkey National Needs Assessment (TNNA) report concluded that Turkey was underachieving in ELT and that this was caused by insufficient teaching in primary and secondary schools. Following the publication of the TNNA, the conduct of a similar study of ELT in Turkish universities was suggested. The results of this furthering study which was described as 'baseline study'

\footnotetext{
* Seden Eraldemir Tuyan. Tel.: +905326644735

E-mail address: sedentuyan@cag.edu.tr
} 
conducted by British Council in Turkey in 2015 were not very satisfactory as well. The findings of this study revealed that the academic programs or internationalization were not supported by the current distribution and curriculum of ELT in Turkish universities. Consequently, preparatory school classes did not address these problems, students entered preparatory schools with low English proficiency levels and poor motivation. As said by the students, lack of motivation was a major reason limiting their progress, which was also confirmed by teachers. As was reflected in the findings of the 'baseline study'(ibid), the universities reported that students' lack of motivation was apparent when their engagement in the lessons and classroom attendance were concerned. As a good example, Çolak (2008) confirms this situation in his study and reports on the "high rates of absenteeism and failure in English courses at universities all over Turkey" (p.4). It seems evident that, to contribute students' success, more comprehensive studies are needed on ELT regarding attitudes toward English language among university students in Turkey.

Examining learners' attitudes toward a foreign language is crucial and plays a very important role in language learning and teaching. As Dewaele (2015) suggests "emotions are at the heart of the foreign language learning process" (p.13) and students' positive or negative emotions regarding the target language results in the growth of their attitudes toward the language itself, the teacher, the classmates, the course materials, and extra-curricular activities or anything associated with the course. Ultimately, these attitudes may determine success or failure in learning that language. While negative attitudes toward the target language may cause demotivation and end up in failure, having positive attitudes can increase students' motivation, facilitate the learning process and lead to success.

Having similar concerns with Çolak (ibid) and recognizing the importance of motivation and that our students' attitudes toward learning English is related to their possible success, we intended to understand our individual students by conducting this study. Our aim was twofold. Firstly, we wanted to have a profile of our own EFL teaching context regarding the above- mentioned 'deficit' through our students' eyes. Secondly, by identifying these attitudinal and motivational profiles, we aimed to prepare a roadmap to help us improve the quality of EFL instruction at our institution. Therefore, for the purpose of this study, we used Attitude/Motivation Test Battery (Gardner, 2004) which we adapted as a 101item Turkish version.

\subsection{Literature review / Theoretical background}

Various social and psychological factors such as the role of the first language, language learning environment, the type of methodology and instruction, learners' motivations, attitudes, and anxiety levels toward the target language, their aptitudes, intelligence, age, personalities, have been assumed to influence language learning (Kiziltepe, 2003). Research over the last three decades has shown that achievement in a second/foreign language is related to students' attitudes and motivation (Clement, Gardner, and Smythe, 1980; Gardner and Lambert, 1972; Gardner and Smythe, 1981; Naiman et al., 1978; Oxford \& Shearin, 1994; Ushioda, 2001; and Dornyei, 2001).

The theoretical framework that served as a basis for this research is The Socio-Educational Model. According to Gardner's (1985) Socio-Educational model of second language acquisition, language learning takes place in the classroom and motivation is an important variable in second language acquisition. Further, it is also proposed that motivation is supported by two other affective components, integrativeness and attitudes toward the learning situation, and that the composite of such attitudes and motivation reflects an integrative motive that promotes language learning.

Gardner's model (ibid) emphasizes that learning another language is different from learning other school subjects in the way that it involves incorporating skills and behavior patterns of another cultural community. The model includes four categories; social milieu, individual differences, learning contexts and outcomes. In this model while social milieu refers to the cultural beliefs held about the target 
language community, individual differences are intelligence, language aptitude, motivation and situational anxiety. Regarding the other two categories, learning contexts denote the formal and informal language training experience and the outcomes comprise both linguistic and nonlinguistic factors, such as positive attitudes toward the target language group or interest in the ongoing language study.

The AMTB was first introduced in Gardner's (1985) social-psychological theory of L2 motivation. Sourced by the Anglo-Francophone bilingual society in Canada, this theory assumes that motivation to learn a second language can be either integrative, as Gardner and Lambert (1972), identify "a desire to be a representative member of the other language community" or instrumental, "a desire to gain social recognition or economic advantages through knowledge of a foreign language" (p.14). Their findings suggested that learners with integrative motivation were more successful in learning a second/foreign language than those with instrumental motivation. However, as was also claimed in later studies (Kachru, 1977; Lukmani, 1972) a second language can be very successfully achieved for instrumental reasons alone. Studies in Turkish EFL context showed that EFL learners had high levels of instrumental motivation toward English (Kızıltepe, 2000; Saracaloğlu, 2000; Üzüm, 2007).

To Gardner (2005) the AMTB was developed to be incorporated to the Socio-Educational model of second language acquisition and therefore it is claimed to be a suitable tool to refer to specific aspects of the model. In this respect, the composition of the AMTB can be grouped into five categories: integrativeness, attitudes toward the learning situation, motivation, language anxiety, and other attributes (Gardner \& MacIntyre, 1993). Accordingly, all the variables in the adapted translated version "Davranış/Motivasyon Testi (AMTB Turkish Version)" belong to the four general categories mentioned above. As the other two attributes that measure 'instrumental orientation' and parental encouragement' were also included in the AMTB English version (2004) and that the instrument appeared to measure variables that are related to second/foreign language learning (Gardner, Tremblay \& Masgoret,1997), they were also examined as two separate categories to interpret the results of this study. Consequently, integrativeness (I) is the total on three scales integrative orientation, attitudes toward the target group, interest in foreign languages; attitudes toward the learning situation (ALS) refer to affective reactions toward the language teacher and the language course; motivation (M) corporates motivational intensity, desire to learn English, attitudes toward learning the language and language anxiety (LA) is measured by English class anxiety and English use anxiety. Finally, the other categories included in the assessment and interpreted as findings were instrumental orientation (IO) which stresses the pragmatic value of learning English to the students, and parental encouragement (PE) which assess the extent to which the students feel their parents' support in learning English.

\subsection{Research Questions}

This research tries to find answers the following questions:

1. What are the attitudes of Turkish tertiary level EFL students towards learning English in terms of the 6 six constructs; Integrativeness; Attitudes towards the Learning Situation; Motivation; Language Anxiety; Instrumental Orientation and Parental Encouragement as measured by the AMTB?

2. Is there any statistically significant difference in the attitudes of Turkish tertiary level EFL students towards learning English in terms of the 6 six constructs; Integrativeness; Attitudes towards the Learning Situation; Motivation; Language Anxiety; Instrumental Orientation and Parental Encouragement measured by the AMTB translated and adapted Turkish version (Gardner, 2004); by

a) Gender?

b) Level of proficiency? 


\section{Method}

\subsection{Design}

This study is a case study conducted in a Turkish university context. According to Berg (1998), "case study methods involve systematically gathering enough information about a particular person, social settings, event, or group to permit the researcher to effectively understand how it operate or function" (p.212). The study is descriptive in nature and aims to identify the attitudinal and motivational profiles of the EFL students in Turkish tertiary context as measured by an adapted 101-item Turkish version of the Attitude/Motivation Test Battery (Gardner, 2004).

\subsection{Participants}

This study took place at a preparatory school of foreign languages in a Turkish state university in 2015-2016 academic year. The participants were 793 preparatory school students whose ages vary between 18-21. $376(50,6 \%)$ of the participants were male, $242(32,6 \%)$ were female and $125(17,2$ $\%)$ didn't mention their gender. The students were not asked to write their names for ethical purposes and the quality of the data collected. Their level of English was determined by an in-house proficiency and a subsequent placement exam to study a one-year intensive English course in the school of foreign languages. Accordingly, the students who took part in this study were studying English at 3 different proficiency levels (A1-beginner, A2-pre-intermediate, B1-intermediate) when data were collected.

\subsection{Instrument}

The data for the present study were collected using AMTB (Gardner, 2004). Before the study began the 103 item-English version of AMTB scale was translated into Turkish by the researcher and two expert colleagues in ELT and back-translated into English by other two experts in the field of translation. The differences were reconciled by comparing the translated version with the original scale. As the context of this study was a preparatory school of English and the students were taking only intensive English courses other than different classes at tertiary level, three questions were deleted from the Turkish version. These questions were mainly; Q20- I would rather spend more time in my English class less than other classes; Q25- My English teacher is better than my other teachers and Q 41- I enjoy the activities of our English class more than those of my other classes. The Kaiser-Meyer-Olkin measure of sampling adequacy (KMO) and Bartlett's test of sphericity were used to assess whether the sample was adequate, and the factor correlation matrix was suitable for factor analysis $(\mathrm{KMO}=0.946, \chi 2=42837.2$ $\mathrm{p}=0.0001$ ). Then, as there were no items in the scale whose MSA values less than 0.50 , no items were deleted from the 101 item- Turkish version. This version consisted of 12 factors, which were listed under 6 main constructs and were also evaluated in the light of the literature (see Table 1).

Table 1. The key to the Turkish AMTB constructs and sub-scales

\begin{tabular}{llr}
\hline Constructs & Scales & Questions \\
\hline \multirow{3}{*}{ Integrativeness (I) } & Integrative orientation (IO) & $33,76,96$ \\
& Attitudes toward the target group (ATG) & $25,27,46,47,50,68,88,101$ \\
Attitudes toward the learning & Interest in foreign languages (IFL) & $1,7,13,20,39,52,56,62$ \\
situation (ALS) & Teacher evaluation (TE) & $5,14,32,43,55,66,75,86,94$ \\
& Course evaluation (CE) & $10,28,30,36,37,49,71,81,99$ \\
Motivation (M) & Motivational intensity (MI) & $3,22,31,41,53,60,64,74,80,84,93$ \\
& Desire to learn English & $8,9,15,17,26,48,69,70,89$ \\
Language Anxiety (LA) & Attitudes toward learning the language & $6,12,18,24,44,58,78,79,87,97$
\end{tabular}


Instrumental Orientation

The Turkish version consisted 101 items with a six-point Likert-type scale from strongly disagree to strongly agree. An analysis of item reliability was determined through the reliability coefficient test by using SPSS version 23.0. The Turkish AMTB was pilot-tested with a group of 50 B1 students and through piloting the questionnaire, the overall Cronbach Alpha reliability was found to be quite high $(\alpha=0.796)$. The reliability estimate of the translated AMTB version was 0.78 . Table 2 shows the reliability of the questionnaire items in terms of the 6 constructs stood as I ( $\alpha=$. 74); ALS $(\alpha=.58)$; M (.63); LA $(\alpha=.79)$; IO (0.83) and PE $(\alpha=.80)$ measured by Turkish AMTB separately.

Table 2. Turkish AMTB Reliability Index

\begin{tabular}{lcl}
\hline \multicolumn{1}{c}{ Constructs } & Item & Cronbach's Alfa \\
\hline I & 19 & $0.74(\% 95$ CI $0.71-0.77)$ \\
ALS & 18 & $0.58(\% 95$ CI $0.51-0.64)$ \\
M & 30 & $0.63(\% 95$ CI $0.57-0.69)$ \\
LA & 17 & $0.79(\% 95$ CI $0.77-0.82)$ \\
INSO & 8 & $0.80(\% 95$ CI $0.81-0.85)$ \\
PE & 9 & $0.83(\% 95$ CI $0.81-0.85)$ \\
Overall AMTB & 101 & $0.78(\% 95$ CI $0.75-0.80)$ \\
\hline N=793 $\mathrm{p}=0.0001$ & &
\end{tabular}

\subsection{Data collection procedures}

This research was conducted in the second block of the first semester of 2015-2016 academic year with participating 793 preparatory school students who are taking intensive English courses at tertiary level. The students were asked to signify the extent to which they agree or disagree with the items of the questionnaire. The time allotted to students to answer the questionnaire was one class hour (40 minutes), which was also confirmed by the pilot study. As the number of the students were high, the researchers explained the content and the instructions of the questionnaire to the faculty members earlier at a general staff meeting, so the administration of the questionnaires by the faculty who are teaching the classes became possible. The questionnaires were delivered to the faculty in envelopes that contain enough printed copies for the required number of students in each class and collected back after the administration procedure. They were also informed to ensure the peace and quiet of the classrooms for the effective administration process of the questionnaire. To increase the credibility of the responses, students did not have to write their names. They were only asked to provide their gender for this study. If the students had any questions concerning the items in the questionnaire, the faculty were supposed to help them to understand the items. The researchers were also around for possible problems during the administration process.

\subsection{Data analysis}

Statistical Package of Social Sciences (SPSS 23.0) was used to analyze the data gathered through the questionnaire. The statistics used for this study included descriptive statistics with mean scores, student's t-test for analyzing differences in 6 AMTB constructs in terms of gender and one-way analysis of variance (ANOVA) for analyzing differences regarding the level of proficiency. 


\section{Results}

Altogether 793 questionnaires were distributed. Out of the 793 students, 618 students were found to mention their gender $(\mathrm{M}=376, \mathrm{~F}=242)$. Their level of proficiency was determined earlier, first at the start of their intensive English education by an in-house proficiency exam, then by a subsequent placement exam that measured and assigned their proficiency levels as A1, A2 and B1 (see Table 3).

Table 3. Distribution of respondents by level of proficiency

\begin{tabular}{lcc}
\hline & $\mathrm{n}$ & $\%$ \\
\hline A1 & 590 & 74,4 \\
A2 & 153 & 19,3 \\
B1 & 50 & 6,3 \\
\hline
\end{tabular}

\subsection{Overall mean rating}

The minimum, maximum and mean scores for the 12 variables were computed and are reported in Table 4 below. These results were interpreted under six main headings (the AMTB constructs) to have an overview of the implications of Gardner's Socio-Educational Model in the context of this study.

Table 4. The mean ratings, minimum and maximum scores for the Turkish AMTB sub-scales

\begin{tabular}{lccc}
\hline \multicolumn{5}{c}{ MEAN } & MINIMUM & MAXIMUM \\
\hline I & & & \\
\hline IO & $19.4 \pm 3.6$ & 5 & 24 \\
AESP & $28.6 \pm 7.7$ & 8 & 48 \\
IFL & $49.7 \pm 6.8$ & 20 & 60 \\
\hline ALS & & & \\
\hline ETE & & 9 & 54 \\
ECE & $44.5 \pm 8.1$ & 8 & 66 \\
\hline M & $35.3 \pm 8.2$ & & 60 \\
\hline MI & & 19 & 60 \\
DLE & $42.3 \pm 7.7$ & 10 & \\
ALE & $47.3 \pm 8.1$ & 10 & 59 \\
\hline E & $49.2 \pm 9.0$ & & 24 \\
\hline EUA & & 13 & 48 \\
\hline INSO & $35.4 \pm 8.3$ & 14 & 4 \\
\hline
\end{tabular}

\subsubsection{Integrativeness}

According to the findings, the mean rating for students' IO was $19.4(\mathrm{SD}=3.6)$ out of a maximum score of 24, which showed that our students often endorsed integrative reasons to study English and permitted social interaction with English- speaking people. Reported mean rating for AESP scale out of a maximum score of 48 was 28.6 ( $\mathrm{SD}=7.7$ ) indicating that the current sample of students had moderate levels of positive attitudes toward English speaking people. Regarding the students' IFL scores, the 
results revealed that the students' general interest toward learning foreign languages in Turkish tertiary context was relatively high $(\mathrm{M}=49.7 \mathrm{SD}=6.8)$ out of a maximum score of 60 .

\subsubsection{Attitudes toward learning situation}

The mean ratings for the two sub-scales showed that students in Turkish context at tertiary level evaluated their EFL course $(M=35.3 \mathrm{SD}=8.2, \max =48)$ and the instructors $(\mathrm{M}=44.5 \mathrm{SD}=8.1, \max =54)$ with moderately high scores.

\subsubsection{Motivation}

In the 101- item Turkish AMTB version, the motivation construct incorporates three sub-scales. Accordingly, the reported means for the MI sub-scale was $42.3(\mathrm{SD}=7.7 \mathrm{max}=66)$ which indicated a moderate degree of effort being spent in learning English. In terms of the students' desire to learn English, the related sub-scale reported means reflected a moderately strong desire (M=47.3 SD=8.1 $\max =60)$ as the participants of this study perceived. According to the findings, the students' attitudes toward learning English was found to be rather positive $(M=49.2 \mathrm{SD}=9$ max=60).

\subsubsection{Anxiety}

The findings of this study revealed that the students often felt discomfort while participating in English class $(\mathrm{M}=35.4 \mathrm{SD}=8.3 \mathrm{max}=59)$ as well as using English $(\mathrm{M}=33.4 \mathrm{SD}=7.8 \mathrm{max}=55)$.

\subsubsection{Instrumental orientation}

A high score in this construct indicates that the student favors instrumental reasons for learning English. Accordingly, the results of this study suggested that our students generally had instrumental motivation to learn English ( $\mathrm{M}=20.3 \mathrm{SD}=3.1 \mathrm{max}=24)$.

\subsubsection{Parental encouragement}

This construct aims to evaluate the extent to which students feel their parents' support in their English study. Consequently, the reported means for this construct indicated a relatively high level of perceived parental encouragement by the students $(\mathrm{M}=38.4 \mathrm{SD}=7.4 \mathrm{max}=48)$.

\subsection{Mean ratings of AMTB sub-scales considering different proficiency levels}

The mean ratings of AMTB sub-scales considering different proficiency levels are given in Table 5 . When the students' reported mean ratings by their proficiency levels were examined, the findings of this study showed that B1 students at our school perceived higher levels of almost all the constructs assessed by AMTB Turkish version, when compared with A1 and A2 students (see also Table 6 for detailed ANOVA results). In that consideration, the mean ratings of A1 students were found to be slightly higher than the scores of the B1 students, in terms of the instrumental orientation and parental encouragement scales. As another finding of this study, A2 students were found to assess the lowest levels of all the AMTB constructs when the mean ratings of the three groups were compared. These results including the mean ratings for Anxiety sub-scales indicated that A2 level students had lower levels of anxiety while participating the English classes and using English. However, the results regarding ECA, EUA and INSNSO scales were not found to be statistically significant ( $p>0.05$ ). 
Table 5. Mean ratings of AMTB sub-scales considering different proficiency levels

\begin{tabular}{lllll}
\hline & $\begin{array}{l}\text { A1 } \\
(\mathrm{N}=590)\end{array}$ & $\begin{array}{l}\text { A2 } \\
(\mathrm{N}=153)\end{array}$ & $\begin{array}{l}\mathrm{B} 1 \\
(\mathrm{~N}=50)\end{array}$ & \\
\hline I & Mean $\pm \mathrm{SD}$ & Mean $\pm \mathrm{SD}$ & Mean $\pm \mathrm{SD}$ & $\mathrm{p}$ \\
\hline IO & $19.4 \pm 3.6$ & $18.9 \pm 3.7$ & $20.6 \pm 2.9$ & $<0.05$ \\
AESP & $28.5 \pm 7.5$ & $27.8 \pm 6.8$ & $31.3 \pm 5.6$ & $<0.05$ \\
IFL & $49.5 \pm 6.9$ & $49.1 \pm 7.0$ & $53.6 \pm 4.4$ & $<0.05$ \\
\hline ALS & & & & \\
\hline ETE & $44.4 \pm 8.1$ & $43.0 \pm 8.9$ & $49.9 \pm 3.4$ & $<0.05$ \\
ECE & $35.2 \pm 8.3$ & $33.4 \pm 7.9$ & $41.8 \pm 4.9$ & $<0.05$ \\
\hline M & & & & \\
\hline MI & $42.4 \pm 6.7$ & $41.4 \pm 7.1$ & $44.0 \pm 6.4$ & $<0.05$ \\
DLE & & & & \\
ALE & $47.3 \pm 8.1$ & $45.3 \pm 8.3$ & $52.6 \pm 4.9$ & $<0.05$ \\
\hline A & $49.1 \pm 9.1$ & $47.5 \pm 8.8$ & $55.4 \pm 4.3$ & $<0.05$ \\
\hline ECA & & & & \\
EUA & $35.3 \pm 8.3$ & $34.8 \pm 8.4$ & $38.0 \pm 8.7$ & $>\mathbf{0 . 0 5}$ \\
\hline INSO & $33.5 \pm 7.7$ & $32.8 \pm 8.0$ & $33.2 \pm 7.5$ & $>\mathbf{0 . 0 5}$ \\
\hline PE & $20.3 \pm 3.1$ & $19.9 \pm 3.1$ & $20.2 \pm 2.4$ & $>\mathbf{0 . 0 5}$ \\
\hline
\end{tabular}

Table 6. The ANOVA results of the AMTB sub-scales in relation to students' proficiency levels

\begin{tabular}{|c|c|c|c|c|c|c|}
\hline & Variance & $\begin{array}{l}\text { Sum of } \\
\text { squares }\end{array}$ & $\mathrm{df}$ & $\begin{array}{l}\text { Mean } \\
\text { Square }\end{array}$ & $\mathrm{F}$ & Sig \\
\hline \multicolumn{7}{|l|}{ I } \\
\hline \multirow[t]{3}{*}{ IO } & BG & 116.6 & 2 & 58.3 & 4.6 & .01 \\
\hline & WG & 100050.97 & 790 & 12.72 & & \\
\hline & $\mathrm{T}$ & 10167.58 & 792 & & & \\
\hline \multirow[t]{3}{*}{ AESP } & BG & 474.73 & 2 & 237.4 & 4.5 & .01 \\
\hline & WG & 41860.05 & 790 & 53 & & \\
\hline & $\mathrm{T}$ & 42334.78 & 792 & & & \\
\hline \multirow[t]{3}{*}{ IFL } & BG & 848.5 & 2 & 424.3 & 9.1 & .00 \\
\hline & WG & 36659.6 & 790 & 46.4 & & \\
\hline & $\mathrm{T}$ & 37508.1 & 792 & & & \\
\hline \multicolumn{7}{|l|}{ ALS } \\
\hline \multirow[t]{3}{*}{ ETE } & BG & 1793 & 2 & 897 & 14 & .00 \\
\hline & WG & 50767.5 & 790 & 64.3 & & \\
\hline & $\mathrm{T}$ & 52561.4 & 792 & & & \\
\hline \multirow[t]{3}{*}{ ECE } & BG & 2675.06 & 2 & 1337.6 & 20.7 & .00 \\
\hline & WG & 51157.1 & 790 & 64.8 & & \\
\hline & $\mathrm{T}$ & 53832.2 & 792 & & & \\
\hline \multicolumn{7}{|l|}{$\mathbf{M}$} \\
\hline \multirow[t]{3}{*}{ MI } & BG & 274.8 & 2 & 137.4 & 3 & .049 \\
\hline & WG & 35813 & 790 & 45.3 & & \\
\hline & $\mathrm{T}$ & 36087.8 & 792 & & & \\
\hline \multirow[t]{3}{*}{ DLE } & BG & 2004.9 & 2 & 1002.4 & 15.7 & .00 \\
\hline & WG & 50560.3 & 790 & 64 & & \\
\hline & $\mathrm{T}$ & & 792 & & & \\
\hline
\end{tabular}




\begin{tabular}{lllllll} 
ALE & BG & 2327.1 & 2 & 1163.6 & 14.9 & .00 \\
& WG & 61829.2 & 790 & 78.3 & & \\
& T & 64156.4 & 792 & & & \\
\hline Anxiety (A) & & & & & & \\
\hline ECA & BG & 400.9 & 2 & 200.45 & 2.9 & $\mathbf{. 0 5 7}$ \\
& WG & 55016.1 & 790 & 69.6 & & \\
EUA & T & 55416 & 792 & & & \\
& BG & 55.7 & 2 & 27.8 & .459 & $\mathbf{. 6 3}$ \\
& WG & 47873.4 & 790 & 60.6 & & \\
\hline INSO & T & 47929.1 & 792 & & & \\
\hline & & & & & & \\
& BG & 18.6 & 2 & 9.3 & .99 & $\mathbf{. 3 7}$ \\
& WG & 7366.2 & 790 & 9.3 & & \\
\hline PE & T & 7384.7 & 792 & & & \\
\hline & & & & & & \\
& BG & 343.6 & 2 & 171.8 & 3.1 & .04 \\
& WG & 43396 & 790 & 54.9 & & \\
\hline
\end{tabular}

\subsection{Mean ratings of students for AMTB sub-scales considering gender}

The mean ratings of 618 students who marked their gender during the administration of AMTB Turkish version were computed separately and estimated accordingly (see Table 7). All the results were found to be statistically significant except for the IM construct ( $p>0.05$ ). The results revealed that the female students who participated in this study perceived higher levels of influence assessed by all the AMTB constructs when compared with male students. This result suggested that the female students in tertiary EFL context had more positive attitudes towards learning English and that they were more motivated than male students in learning English. However, the higher scores of female students regarding A sub-scales of AMTB also suggested that they were more anxious than the male students while participating the English classes and speaking English.

Table 7. AMTB sub-scale results in relation to gender

\begin{tabular}{lcccc}
\hline & $\begin{array}{c}\mathrm{M}(\mathrm{N}=376) \\
\mathrm{Mean} \pm \mathrm{SD}\end{array}$ & $\begin{array}{c}\mathrm{F}(\mathrm{N}=242) \\
\mathrm{Mean} \pm \mathrm{SD}\end{array}$ & $\mathrm{t}$ & $\mathrm{p}$ \\
\hline I & & & & \\
IO & $19.2 \pm 3.5$ & $20.3 \pm 3.1$ & 4.4 & $<0.05$ \\
AESP & $28.0 \pm 7.4$ & $30.5 \pm 6.5$ & 4.5 & $<0.05$ \\
IFL & $49.3 \pm 6.7$ & $51.6 \pm 5.7$ & 4.5 & $<0.05$ \\
ALS & & & & \\
ETE & $44.6 \pm 8.1$ & $47.0 \pm 6.6$ & 4 & $<0.05$ \\
ECE & $34.9 \pm 8.1$ & $37.5 \pm 7.3$ & 4 & $<0.05$ \\
M & & & & \\
MI & $41.7 \pm 6.6$ & $44.4 \pm 6.1$ & 5.1 & $<0.05$ \\
DLE & $47.0 \pm 8.1$ & $49.3 \pm 6.9$ & 3.8 & $<0.05$ \\
ALE & $48.6 \pm 9.3$ & $51.7 \pm 7.3$ & 4.7 & $<0.05$ \\
A & & & & \\
ECA & $33.6 \pm 8.1$ & $37.8 \pm 8.2$ & 6.3 & $<0.05$ \\
EUA & $32.0 \pm 8.1$ & $35.2 \pm 7.3$ & 5.2 & $<0.05$ \\
INSO & $20.2 \pm 3.2$ & $20.7 \pm 2.7$ & 1.9 & $>\mathbf{0 . 0 5}$ \\
PE & $37.5 \pm 8.1$ & $40.2 \pm 6.2$ & 4.7 & $<0.05$ \\
\hline
\end{tabular}




\section{Discussion}

The attitudes and motivation of Turkish tertiary level EFL students towards learning English in terms of the 6 six constructs; I; ALS; M; LA; IO and PE as measured by the AMTB were investigated for the purpose of this study. The data collected from 793 participating students at tertiary level were also subjected to analysis in terms of level of proficiency and gender. The results will be discussed in detail under each AMTB construct in the following sub-sections.

\subsection{Integrativeness}

Gardner et al. (2004) note that integrativeness in the socio-educational model is "represented by three scales measuring ALG, IFL, and IO. Regarding the results of these scales that represent $\boldsymbol{I}$ construct obtained from this study, our students often had integrative orientation to study English and permitted social interaction with English-speaking people, had moderate levels of positive attitudes towards English-speaking people and generally had high interest in foreign languages. Among the three subscales represented by the $\boldsymbol{I}$ construct, our students' reported mean score showing their moderate level of positive attitudes toward English-speaking people $(M=28.6 \mathrm{SD}=7.7 \mathrm{max}=48)$ in some way revealed their disagreement related to this sub-scale when compared to the mean ratings of the other two sub-scales. In this regard, Gardner (2005) asserts that learners who see their ethnolinguistic heritage as not a major part of their cultural and national identity are likely to have higher integrativeness in learning the target language. Hence, this relatively low score might have been caused by some of the students' religious or cultural beliefs, as Turkey being a Muslim country and some traditions' and habits' being different from the so-called values of the English-speaking people, some students might have resisted understanding the target culture or mixing culturally or socially.

Considering the students' proficiency levels, the findings of this study showed that B1 students had the highest levels of all the sub-scales of $\boldsymbol{I}$ construct when compared to A1 and A2 students (see Table $5 \&$ Table 6). This result might suggest a positive relationship between the level of proficiency and integrativeness of the Turkish tertiary level EFL students and requires a further study. Additionally, in ranking the students' proficiency levels, A2 students were found to receive the lowest levels in terms of $\boldsymbol{I}$ sub-scale mean scores and this interesting finding was consistent with all the results obtained from the other five AMTB constructs. This result may have been triggered by the low proficiency level and poor motivation of A2 level students, who mostly had insufficient English education in primary and secondary schools as was mentioned earlier (TNNA report, 2013). These students usually start the intensive English course given at YADYO neither from the A1 nor the B1 levels because of their scores in placement test they take before starting their EFL education.

The results of this study also showed a statistically significant difference between male and female students in the three sub-scales represented by $\boldsymbol{I}$ construct. This finding is in line with that of Solak's study (2012) which also discovered that Turkish female students were more integratively motivated than their male peers $(\mathrm{p}=.015)$.

\subsection{Attitudes toward learning situation}

The reported mean ratings for the two sub-scales as represented by ALS construct of the Turkish AMTB showed that students at tertiary level evaluated their EFL instructors and the intensive English course given at our prep school with moderately high scores (see Table $5 \&$ Table 6). Moreover, like the findings obtained from the sub-scales of the $\boldsymbol{I}$ construct, B1 students were found to have more positive attitudes toward their EFL instructors and the language course followed by A1 students when their level of proficiency was considered. Looking at the difference between female and male students regarding their attitudes toward learning situation, it can be concluded that the current study found a 
statistically significant difference between the means of both groups. The t-test also showed that female students' attitudes toward the teacher $(M=47)$ and the course $(M=37.5)$ were more positive than those of male students $(\mathrm{Mt}=44.6 \mathrm{Mc}=34.9)$. In the current study, the $\mathrm{p}$-value $(\mathrm{p}<0.05)$ which indicates that a true difference existed between the two groups. This difference could be attributed to cultural factors that Turkish families tend to bring up their daughters in a more traditional way regarding respect, cooperativeness and understanding which paid as better relationship with their teachers when compared to their male counterparts. Our findings also support the findings of Kiziltepe's study (1997), who suggests that female students scored higher in different sub-scales in her study, that Turkish girls are more ambitious and hardworking in nature and the conservative attitude of Turkish parents toward girls made them more careful in their studies.

\subsection{Motivation}

In the AMTB, the three components of effort, desire and positive affect in motivation are assessed using the three sub-scales: MI, DLL and ALL. The findings of this study showed that Turkish students in tertiary context spent medium level of effort in studying English, while they felt a fairly strong desire. Their attitudes toward learning English were also found to be quite positive. It is thought-provoking that the reported means for students' MI mirrored a medium level of effort for studying English, which meant they didn't put enough effort for doing homework or became highly diligent, independent learners who practice regularly to improve their proficiency levels. This finding suggests that institutions which aim improvement in their EFL teaching policies in Turkish tertiary context need to target a more autonomous approach on part of the students to achieve more fruitful outcomes.

Looking at the reported mean scores of the sub-scales represented by the M construct of the AMTB regarding the proficiency levels of the students (see Table $5 \&$ Table 6), like the findings obtained from $I$ and ALS constructs, B1 students were found to assess the highest levels, followed by A1 and A2 students respectively. This finding suggests a positive relationship between students' motivation in learning English and their EFL proficiency.

In terms of the mean scores obtained from the motivation sub-scales of the AMTB, the female students' motivation was found to be significantly higher than the males. This finding was similar to those of the studies conducted by Gökçe (2008) with tenth grade high schoolers and Nahavadi and Makundan (2013) in a general EFL course setting related to the students' motivational intensity in learning English.

\subsection{Anxiety}

Considering the mean ratings of the sub-scales obtained by the anxiety construct of the AMTB, the findings of this study revealed that our students often felt discomfort while participating in English class as well as using English (see Table 5 and Table 6). This finding of the study signaled an important challenge to be faced and dealt with for the ultimate success of tertiary level students in Turkish context considering the negative influence of anxiety on EFL learning. The finding also indicated that students' failure in EFL learning might have been caused by their high anxiety levels. On the other hand, despite being not statistically significant, the results of this study revealed that in terms of their proficiency level, A2 students were the least anxious group among the three. Related to this, A1 students were found to be the most anxious group in using English whereas B1 students were more anxious than A1 students in participating English class. However, remarkably, related to this construct only, female students were identified as significantly more anxious than their male counterparts. This result is consistent with the findings of the studies conducted by Padilla et al. (1988) and AyashEzzi (2012) who found that girls were more concerned about language complications and felt more worried. 


\subsection{Instrumental orientation}

As was stated by Norris-Holt (2001), when students are instrumentally motivated, the aim of language learning "is more utilitarian, such as meeting the requirements for school or university graduation, applying for a job, requesting higher pay based on language ability, reading technical material, translation work or achieving higher social status (p.1). The reported mean scores for INSO construct as measured by the AMTB suggested that the Turkish EFL students in tertiary context were instrumentally motivated in general. When this result was compared to the students' estimated IO subscale scores it was seen that the participants of the current study were slightly more instrumentally motivated (see Table 4). Considering the different proficiency levels, despite being not statistically significant ( $p>0,05)$, slight differences were found out of a maximum score of 24 among the three groups; A1 (M=20.3 SD=3.1), A2 (M=19.9 SD=3.1), B1 (M=20.2 SD=2.4). On the other hand, the study didn't find any significant difference between male and female students in regard to instrumental motivation and in that of the reported mean scores, there was only a minor difference $(\mathrm{Mm}=20.2 \mathrm{SD}=$ 3.2 $\mathrm{Mf}=20.7 \mathrm{SD}=2.7$ ), indicating the instrumental motivation of female students' being slightly higher than their male counterparts. Similar to the findings of our study, Öztürk and Gürbüz (2013) didn't find any significant difference between male and female students' instrumental orientations in Turkish tertiary EFL context. Overall, the results obtained from the INSO construct of the AMTB showed that regardless of level of proficiency and gender, the Turkish students in tertiary EFL context are generally aware of the importance of learning English for their academic, job-related, financial and social-status requirements.

\subsection{Parental Encouragement}

The questions in this sub-scale were intended to measure the students' evaluations on how they perceived their families' interest in their learning English, mainly related to their consideration of learning English as important to devote time, improve, be consistent, attend to the classes and assist for any kind of help for their children's learning English. The reported means for this construct indicated a relatively high level of perceived parental encouragement $(80 \%)$ by Turkish EFL students in tertiary context (see Table 4). Moreover, a statistically significant difference was found when the three proficiency levels were considered. Accordingly, A1, the beginner group was found to perceive getting more parental support when compared to the findings regarding A2 and B1 groups. In this ranking, A2 students in Turkish tertiary context were identified to perceive more parental encouragement than the B1 students. The findings of this study also revealed that there is significant difference between male and female students regarding their perceptions of parental encouragement and that the female students perceived this positive influence more than their male peers. This result is in agreement with that of AlDosari (2016), who found that female students received more parental encouragement than males in Arabic context. According to Al-Dosari (ibid), this result might be due to the general idea of Arab world regarding the importance of a girl's security in supporting herself by getting a degree in case of divorce or loss of husband as well as the concern for contributing to family income or at least being able to pay her own expenses. Similar reasons might be attributed to the results of our study, as Turkey is a country with Islamic background and that many Turkish families have similar ways of thinking regarding a girl's security and financial independence.

\section{Conclusions}

The main purpose of the study was to identify the attitudinal and motivational profiles of tertiary level EFL students in Turkish context through the AMTB which was developed to be incorporated to 
the Socio-Educational Model of second language acquisition (Gardner, 2005). In summary, our investigation demonstrated that the participants of this study had a moderate level of positive attitudes toward English-speaking people despite their relatively high level of integrative orientation to study English and interest in foreign languages. This result indicated a disagreement which could be a barrier in their EFL studies. It is recommended that students should be encouraged to take part in exchange programs, like ERASMUS in higher education to have the opportunity to share with English-speaking students. Students can also be assigned different personal and group projects to investigate the cultural and traditional characteristics of English-speaking people to practice different language skills as well as to help them improve their positive attitudes toward the English-speaking people. Alternatively, as suggested by Oxford and Shearin (1994), "teachers can also invite visitors who are native speakers of the L2 to share cultural information and confirm that the students can really use the language communicatively" (p. 24).

As another interesting finding, considering the proficiency levels of the participating students, A2 level students were found to have the lowest mean scores while B1 students scored highest in most of the AMTB scales, which suggested that this group of students had more positive attitudes toward learning English and were more motivated to learn English when compared to A1 and A2 level students. The comparatively low motivation of A2 level students was attributed to the 'insufficient teaching of English in primary and secondary schools in Turkey' as was informed by the TNNA report in 2013.

Furthermore, the study also concluded that the current sample of students in Turkish tertiary EFL context often felt anxious, and that female students were more anxious than the male students. It is recommended that the reasons for students' anxiety should be explored from different aspects as it may cause students failure in learning English. The EFL instructors are also suggested to try different strategies to help reduce students' anxiety levels and avoid anxiety provoking situations or language tasks in their EFL classrooms.

In all the other estimates of the AMTB scales except for anxiety, female students were found to have higher mean scores when compared to their male counterparts and therefore were identified to have more positive attitudes and be more motivated toward learning English. Finally, besides the high level of perceived parental encouragement showed by all the participants, the female participants of this study were discovered to receive more parental encouragement in comparison with their male peers.

All in all, the findings of this study revealed evidence that the AMTB can be used as an effective tool to measure the attitudinal, motivational as well as the anxiety levels of Turkish EFL students in tertiary context.

Despite not being completely generalizable, the results of this study might provide guidance and contribute to the understanding of EFL/ESL teachers, curriculum developers, school managers and department coordinators of EFL institutions at tertiary level regarding their students' attitudinal and motivational profiles that should be considered in the teaching and learning process. Different results could potentially be obtained from different institutions differing in size, mission or various other factors. Therefore, researchers in different contexts can analyze the impacts of the AMTB factors that influence their students' motivation and attitudes toward learning English, identify the problems that might stand as barriers to their students' success and prepare possible roadmaps that might create more successful outcomes.

\section{Acknowledgements}

In the first place, as authors, we would like to thank R.C. Gardner for granting permission to use the AMTB, adapt this measure to Turkish tertiary context, translate into Turkish and providing supportive 
documents to the conduct of this study. Secondly, we thank Çukurova University students who studied English during 2015-2016 academic year at YADYO, the School of Foreign Languages, for participating in this research. Finally, we thank our colleagues and the translation experts at Çukurova University for their contributions to the adaptation, translation and administration of the scale.

\section{References}

Al-Dosari, N. F. N. (2016). The differences of attitudinal and motivational factors amongst students in Qatar and the relationship between these factors and their achievement in English language. Doctoral thesis, University of Sunderland.

Berg, L. B. (1998). Qualitative research methods for social sciences. Boston: Allyn \& Bacon.

Clément, R. Gardner, R., \& Symthe, P. C. (1980). Social and individual factors in second language acquisition. Canadian Journal of Behavioural Science/ Revue Canadienne des sciences $d u$ comportement, 12(4), pp.293-302. http://dx.doi.org/10.1037/h0081081

Çolak, A. (2008). Attitudes, motivation and study habits of English language learners: The case of Başkent university second-year students. Unpublished PhD thesis. [Online]. Middle East Technical University. Available from: http://etd.lib.metu.edu.tr/upload/12609907/index.pdf?viewType=Print\&viewClass=Print

Dornyei, Z. (2001). Motivational strategies in the language classroom. Cambridge: Cambridge University Press.

Dewaele, J.M. (2015 May/June). On Emotions in Foreign Language Learning and Use. The Language Teacher Online 39.3, 13-15. http://jalt-publications.org/tlt

Gardner, R.C. (1985). Social Psychology and Second Language Learning: The Role of Attitudes and Motivation. London: E. Arnold.

Gardner, R. C. (2004). Attitude/Motivation Test Battery: International AMTB Research Project (English Version). [Online]. Available from: http://publish.uwo.ca/ gardner/docs/englishamtb.pdf [Accessed: 10 April 2014].

Gardner, R.C. (2005). Integrative motivation and second language acquisition. Canadian Association of Applied Linguistics/Canadian Linguistics Association Joint Plenary Talk, London, Canada. [Online]. Available from: http://publish.uwo.ca/ gardner/docs/caaltalk5final.pdf. [Accessed: 11 September 2017].

Gardner, R. C., \& Lambert, W. E. (1972). Attitudes and motivation in second-language learning. Rowley, Massachusetts: Newbury House Publishers.

Gardner, R. C. \& MacIntyre, P. D. (1993). A student's contribution to Second Language Learning: Part II, Affective Factors. Language Teaching, 26, 1-11.

Gardner, R. C. \& Smythe, P.C. (1981). On the development of the attitude/motivation test battery, Canadian Modern Language Review, 37, 510-525

Gardner, R.C., Tremblay, P.F. \& Masgoret, A.-M. (1997). Toward a Full Model of Second Language Learning: An Empirical Investigation. The Modern Language Journal. 81 (3). 344-362. https://doi.org/10.1111/j.1540-4781.1997.tb05495.x

Kachru, B. B. (1977). The new Englishes and old models. English Language Forum, 15, 3, 29-35. 
Gökçe, S. (2008). Attitudes and motivational intensity of foreign language learners at vocational high schools: A comparative study. Ph.D. [Online]. Middle East Technical University. Available from: https://etd.lib.metu.edu.tr/upload/3/12609935/index.pdf. [Accessed: 22 October 2016].

Kiziltepe, Z. (2000). Attitudes and motivation of Turkish EFL students towards second language learning. ITL-International Journal of Applied Linguistics. 129 (1). 141-168

Kiziltepe, Z. (2003). Considering Gender with Attitudes and Motivation of EFL Students. Education and Science, 28 (130).

Lukmani, Y.M. (1972). Motivation to learn and language proficiency. Language Learning. 22 (2). 261-273.

Nahavandi, N. \& Mukundan, J. (2013). Iranian EFL Engineering Students' Motivational Orientations toward English Language Learning along Gender and Further Education in Language Institutes. International Journal of Linguistics. [Online]. 5(1). Available from: http://www.macrothink.org/journal/index.php/ij]/article/view/2684. [Accessed: 27 September 2015].

Naiman, N., Fröhlich, M., Stern, H. H., \& Todesco, A. (1978). The good language learner (Research in Education Series No. 7). Toronto, Canada: Ontario Institute for Studies in Education.

Norris-Holt, J. (2001). Motivation as a Contributing Factor in Second Language Acquisition. [Online]. 2001. Available from: http://iteslj.org/Articles/NorrisMotivation.html. [Accessed: 18 December 2015].

Öztürk, G. \& Gürbüz, N. (2013). The impact of gender on foreign language speakinganxiety and motivation. Procedia . Social and Behavioral Sciences. [Online]. 70. 654-665. Available from: http://linkinghub.elsevier.com/retrieve/pii/S1877042813001079.

[Accessed: 18 October 2015].

Oxford, R., \& Shearin, J. (1994). Language Learning Motivation: Expanding the Theoretical Framework. Modern Language Journal, 78. https://doi.org/10.1111/j.1540-4781.1994.tb02011.x

Saracaloğlu, A. S. (2000). The Relation Between Trainee Teachers' Attitudes to Foreign Languages and their Academic Success. Eğitim ve Bilim Dergisi. Ankara.

Solak, E. (2012). Exploring the role of motivational factors in the academic achievement of EFL learners. ELT Research Journal. [Online]. 1 (4). pp. 240-254. Available from: http://www.eltrj.com/journals/index.php/elt/article/view/49. [Accessed: 21 January 2016].

TEPAV \& British Council. (November, 2015). The state of English in Turkey: A Baseline Study. Yorum Basin Yayın Sanayi Ltd. Şti., Ankara. ISBN 978-0-86355-786-6

Ushioda, E. (2001) Language learning at university: Exploring the role of motivational thinking. In: Dörnyei, Z. and Schmidt, R., (eds.) Motivation and second language acquisition. Honolulu, HI: University of Hawaii, Second Language Teaching and Curriculum Center, pp. 93125. ISBN 978-08248245-8-7

Üzüm, B. (2007). Analysis of Turkish learners' attitudes toward s English language and English speaking societies. Unpublished MA thesis. [Online]. Middle East Technical University. Available from: https://etd.lib.metu.edu.tr/upload/12608571/index.pdf. [Accessed: 27 September 2015]. 


\section{Appendix. The AMTB Turkish version}

\section{DAVRANIŞ/MOTIVASYON TESTİ (AMTB Türkçe Versiyonu)}

Sinifi:

Öğrencinin Ad1:

Öğretmenin Adı:

Birinci Bölüm: Sevgili öğrencimiz, aşă̆ıdaki ifadeler sizin İngilizceyi yabancı dil olarak öğrenmek konusundaki motivasyonunuzu ve bu dili ögrenmeye karşı olan tutumunuzu değerlendirmeyi hedeflemektedir. Ders öğretmeniyle ilgili sorulara cevap verirken haftalık olarak en çok ders aldiğınız bir ögretmeninizi düşünerek değerlendirme yapınız. Doğru veya yanlış cevap olmadığını unutmayınız ve mümkün olduğunca cevapların 1'den 6'ya kadar derecelendirilmesini öngören aşağıdaki ölçeği kullanarak size en yakın gelen cevabı işaretleyiniz. Dilerseniz isminizi yazmayabilirsiniz.

Teşekkürler (:)

\begin{tabular}{|ll|}
\hline 1. & Kesinlikle katılmiyorum \\
\hline 2. & Kismen katılmiyorum \\
\hline 3. & Katılmiyorum \\
\hline 4. & Kismen katıllyorum \\
\hline 5. & Katıliyorum \\
\hline 6. & Kesinlikle katıliyorum. \\
\hline
\end{tabular}

\begin{tabular}{|c|c|c|c|c|c|c|}
\hline $\begin{array}{l}\text { 1. Keşke birçok yabancı dili mükemmel düzeyde } \\
\text { konuşabilsem... }\end{array}$ & 1 & 2 & 3 & 4 & & 6 \\
\hline $\begin{array}{l}\text { 2. Ailem bana İngilizce öğrenmem konusunda yardımc1 } \\
\text { olmak için çaba gösterir. }\end{array}$ & 1 & 2 & 3 & $\overline{4}$ & & 6 \\
\hline $\begin{array}{l}\text { 3. İngilizce dersinde aldığım geri bildirimleri pek fazla } \\
\text { önemsemiyorum. }\end{array}$ & 1 & 2 & 3 & 4 & & 6 \\
\hline $\begin{array}{l}\text { 4. İngilizce dersinde bir soruya yanıt vermem gerektiğinde } \\
\text { geriliyorum. }\end{array}$ & 1 & 2 & 3 & 4 & & 6 \\
\hline $\begin{array}{l}\text { 5. Derse gitmeyi dört gözle bekliyorum çünkü İngilizce } \\
\text { ögretmenim çok iyidir. }\end{array}$ & 1 & 2 & 3 & 4 & & 6 \\
\hline 6. İngilizce öğrenmek gerçekten harika... & 1 & 2 & 3 & 4 & & 6 \\
\hline $\begin{array}{l}\text { 7. Eğer Türkiye'nin İngilizce konuşan ülkelerle iletişimi } \\
\text { olmasayd, bu büyük bir kayıp olurdu. }\end{array}$ & 1 & 2 & 3 & 4 & & 6 \\
\hline $\begin{array}{l}\text { 8. İngilizce öğrenmek önemlidir, çünkü İngilizce bilmek bu } \\
\text { dili konuşan insanlarla daha kolay iletişim kurmamı } \\
\text { sağlıyor. }\end{array}$ & 1 & 2 & 3 & 4 & & 6 \\
\hline $\begin{array}{l}\text { 9. İngilizceyi her yönüyle öğrenmek konusunda güçlü bir istek } \\
\text { duyuyorum. }\end{array}$ & 1 & 2 & 3 & 4 & & 6 \\
\hline 10. Aldığım İngilizce dersi gerçekten zaman kaybıdır. & 1 & 2 & 3 & 4 & & 6 \\
\hline 11. Bir turist ile İngilizce konuşmak zorunda kalsam gerilirim. & 1 & 2 & 3 & 4 & & 6 \\
\hline 12. Yabancı dil öğrenmek eğlenceli değildir. & 1 & 2 & 3 & 4 & & 6 \\
\hline $\begin{array}{l}\text { 13. Gördüğüm ve duyduğum her türlü İngilizceyi anlamaya } \\
\text { çalışyorum. }\end{array}$ & 1 & 2 & 3 & 4 & & 6 \\
\hline 14. İngilizce öğretmenimin çok iyi olmadığını düşünüyorum. & 1 & 2 & 3 & 4 & & 6 \\
\hline $\begin{array}{l}\text { 15. İngilizce öğrenmek önemlidir çünkü ilerde kariyerim için } \\
\text { İngilizceye ihtiyacım olacak. }\end{array}$ & 1 & 2 & 3 & 4 & & 6 \\
\hline $\begin{array}{l}\text { 16. Derste İngilizce konuşurken asla kendimden emin } \\
\text { olamıyorum. }\end{array}$ & 1 & 2 & 3 & 4 & & 6 \\
\hline
\end{tabular}




\begin{tabular}{|c|c|c|c|c|c|c|}
\hline $\begin{array}{l}\text { 17. İngilizce bilmek hayatımda o kadar da önemli bir amaç } \\
\text { değildir. }\end{array}$ & 1 & 2 & 3 & 4 & 5 & 6 \\
\hline 18. İngilizceden nefret ediyorum. & 1 & 2 & 3 & 4 & 5 & 6 \\
\hline $\begin{array}{l}\text { 19. İngilizce konuşmak zorunda kaldığımda kendimi çok rahat } \\
\text { hissediyorum. }\end{array}$ & 1 & 2 & 3 & 4 & 5 & 6 \\
\hline $\begin{array}{l}\text { 20. Birçok yabancı dilde yazılmış gazete ve dergileri } \\
\text { okuyabilmek isterim. }\end{array}$ & 1 & 2 & 3 & 4 & 5 & 6 \\
\hline $\begin{array}{l}\text { 21. Ailem, İngilizce öğrenmemin benim için çok önemli } \\
\text { olduğunu düşünüyor. }\end{array}$ & 1 & 2 & 3 & 4 & 5 & 6 \\
\hline $\begin{array}{l}\text { 22. İngilizce öğretmenimden kontrol edilmiş ödevlerimi geri } \\
\text { aldığımda yanlışlarımın doğrularını öğrenmek benim için } \\
\text { önemli değildir. }\end{array}$ & 1 & 2 & 3 & 4 & 5 & 6 \\
\hline $\begin{array}{l}\text { 23. İngilizce dersimde konuşmam istendiğinde kendime } \\
\text { güvenirim. }\end{array}$ & 1 & 2 & 3 & 4 & 5 & 6 \\
\hline 24. İngilizce öğrenmekten gerçekten zevk alıyorum. & 1 & 2 & 3 & 4 & 5 & 6 \\
\hline $\begin{array}{l}\text { 25. Ana dili İngilizce olan insanların birçoğu cana yakındır ve } \\
\text { onlarla geçinmek kolaydır; onlar arkadaşımız olduğu için } \\
\text { şanslıyız. }\end{array}$ & 1 & 2 & 3 & 4 & 5 & 6 \\
\hline $\begin{array}{l}\text { 26. İngilizce öğrenmek önemlidir çünkü daha fazla ve çeşitli } \\
\text { insanla tanışmamı ve görüşmemi sağlıyor. }\end{array}$ & 1 & 2 & 3 & 4 & 5 & 6 \\
\hline $\begin{array}{l}\text { 27. Bana kalsa zamanımın hepsini İngilizce öğrenmek için } \\
\text { kullanırım. }\end{array}$ & 1 & 2 & 3 & 4 & 5 & 6 \\
\hline 28. Bence İngilizce dersi sıkıcıdır. & 1 & 2 & 3 & 4 & 5 & 6 \\
\hline 29. Herhangi bir yerde İngilizce konuştuğumda gerilirim. & 1 & 2 & 3 & 4 & 5 & 6 \\
\hline 30. Yabancı dillere karş1 gerçekten hiç ilgi duymuyorum. & 1 & 2 & 3 & 4 & 5 & 6 \\
\hline $\begin{array}{l}\text { 31. Neredeyse her gün çalışarak İngilizcemi belli bir düzeyde } \\
\text { tutarım. }\end{array}$ & 1 & 2 & 3 & 4 & 5 & 6 \\
\hline 32. İngilizce öğretmenimi ne kadar az görürsem o kadar iyidir. & 1 & 2 & 3 & 4 & 5 & 6 \\
\hline $\begin{array}{l}\text { 33. İngilizce öğrenmek önemlidir; çünkü bu sayede daha iyi bir } \\
\text { eğitim almış olacağım. }\end{array}$ & 1 & 2 & 3 & 4 & 5 & 6 \\
\hline $\begin{array}{l}\text { 34. Derste sorulan sorulara gönüllü olarak cevap vermeye } \\
\text { çekinirim. }\end{array}$ & 1 & 2 & 3 & 4 & 5 & 6 \\
\hline 35. Bazen İngilizce öğrenmeyi bırakmak isterim. & 1 & 2 & 3 & 4 & 5 & 6 \\
\hline $\begin{array}{l}\text { 36. Zamanımı İngilizce dışındaki konularla harcamayı tercih } \\
\text { ederim. }\end{array}$ & 1 & 2 & 3 & 4 & 5 & 6 \\
\hline 37. İngilizce konuşabilmek çok da umurumda değildir. & 1 & 2 & 3 & 4 & 5 & 6 \\
\hline 38. Ana dili İngilizce olan birçok arkadaşım olsun isterdim. & 1 & 2 & 3 & 4 & 5 & 6 \\
\hline 39. Birçok yabancı dil öğrenmeyi gerçekten isterim. & 1 & 2 & 3 & 4 & 5 & 6 \\
\hline $\begin{array}{l}\text { 40. Ailem, okulum süresince İngilizce öğrenmeye devam } \\
\text { etmem gerektiğini düşünüyor. }\end{array}$ & 1 & 2 & 3 & 4 & 5 & 6 \\
\hline 41. İngilizce ödevlerimi özensiz yaparım. & 1 & 2 & 3 & 4 & 5 & 6 \\
\hline 42. İngilizce konuşmam istendiğinde heyecanlanmam. & 1 & 2 & 3 & 4 & 5 & 6 \\
\hline $\begin{array}{l}\text { 43. İngilizce öğretmenimin dinamik ve ilginç bir öğretme tarzı } \\
\text { var. }\end{array}$ & 1 & 2 & 3 & 4 & 5 & 6 \\
\hline 44. İngilizce, okul programının çok önemli bir parçasıdır. & 1 & 2 & 3 & 4 & 5 & 6 \\
\hline $\begin{array}{l}\text { 45. Ailem, okul bittiğinde İngilizce biliyor olmamın benim } \\
\text { için ne kadar önemli olduğunu vurgular. }\end{array}$ & 1 & 2 & 3 & 4 & 5 & 6 \\
\hline 46. Ana dili İngilizce olan kişiler çok sosyal ve naziktirler. & 1 & 2 & 3 & 4 & 5 & 6 \\
\hline $\begin{array}{l}\text { 47. İngilizce öğrenmek önemlidir çünkü böylece İngilizlerin } \\
\text { yaşam tarzını daha iyi anlayarak değerlendirebileceğim. }\end{array}$ & 1 & 2 & 3 & 4 & 5 & 6 \\
\hline 48. İngilizceyi anadilim gibi ögrenmek istiyorum. & 1 & 2 & 3 & 4 & 5 & 6 \\
\hline $\begin{array}{l}\text { 49. Dürüst olmak gerekirse, İngilizce dersime gerçekten çok } \\
\text { az ilgi duyuyorum. }\end{array}$ & 1 & 2 & 3 & 4 & 5 & 6 \\
\hline $\begin{array}{l}\text { 50. Dünyaya daha çok değer verdikleri için, ana dili İngilizce } \\
\text { olanların gurur duyacakları daha çok şey var. }\end{array}$ & 1 & 2 & 3 & 4 & 5 & 6 \\
\hline $\begin{array}{l}\text { 51. Telefonda İngilizce konuşmak zorunda kalsam rahatsız } \\
\text { hissederim. }\end{array}$ & 1 & 2 & 3 & 4 & 5 & 6 \\
\hline 52. Yabancı dil öğrenmek biz Türkler için önemli değildir. & 1 & 2 & 3 & 4 & 5 & 6 \\
\hline
\end{tabular}




\begin{tabular}{|c|c|c|c|c|c|c|}
\hline $\begin{array}{l}\text { 53. Derste bir şeyi anlamada sorun yaşadığımda her zaman } \\
\text { ögretmenimden yardım isterim. }\end{array}$ & 1 & 2 & 3 & 4 & 5 & 6 \\
\hline $\begin{array}{l}\text { 54. Ailem, İngilizce ile sorunum olduğunda öğretmenimden } \\
\text { yardım istemem konusunda israrcıdır. }\end{array}$ & 1 & 2 & 3 & 4 & 5 & 6 \\
\hline 55. İngilizce öğretmenim tanıdığım en kaba insanlardan biridir. & 1 & 2 & 3 & 4 & 5 & 6 \\
\hline $\begin{array}{l}\text { 56. İngilizce öğrenmek önemlidir çünkü bana iyi bir iş } \\
\text { bulmamda faydalı olacak. }\end{array}$ & 1 & 2 & 3 & 4 & 5 & 6 \\
\hline $\begin{array}{l}\text { 57. Sınıfımdaki diğer öğrencilerin benden daha iyi İngilizce } \\
\text { konuşması beni endişelendirir. }\end{array}$ & 1 & 2 & 3 & 4 & 5 & 6 \\
\hline $\begin{array}{l}\text { 58. İngilizce öğrenme konusundaki tüm isteğimi } \\
\text { kaybediyorum. }\end{array}$ & 1 & 2 & 3 & 4 & 5 & 6 \\
\hline 59. İngilizce öğrenmek gerçekten zaman kaybıdır. & 1 & 2 & 3 & 4 & 5 & 6 \\
\hline $\begin{array}{l}\text { 60. İngilizce yol tarifi yapmak zorunda kalsam rahatça } \\
\text { yapabilirim. }\end{array}$ & 1 & 2 & 3 & 4 & 5 & 6 \\
\hline $\begin{array}{l}\text { 61. İngilizce sınıfımı çok seviyorum, gelecekte daha fazla } \\
\text { İngilizce öğrenmek istiyorum. }\end{array}$ & 1 & 2 & 3 & 4 & 5 & 6 \\
\hline $\begin{array}{l}\text { 62. Başka bir ülkede yaşamayı planlasam, dillerini öğrenmeyi } \\
\text { denerim. }\end{array}$ & 1 & 2 & 3 & 4 & 5 & 6 \\
\hline 63. Ailem, İngilizce sınıfımda yaptığım her şeyle çok ilgilidir. & 1 & 2 & 3 & 4 & 5 & 6 \\
\hline $\begin{array}{l}\text { 64. İngilizce öğretmenimin herhangi bir şey için yaptı̆̆ } \\
\text { açıklamayı anlamadığımda vazgeçer ve dikkatimi } \\
\text { kaybederim. }\end{array}$ & 1 & 2 & 3 & 4 & 5 & 6 \\
\hline $\begin{array}{l}\text { 65. Diğer öğrencilerin sinıfta İngilizce konuşmak konusunda } \\
\text { kendilerini neden gergin hissettiklerini anlamıorum. }\end{array}$ & 1 & 2 & 3 & 4 & 5 & 6 \\
\hline $\begin{array}{l}\text { 66. İngilizce öğretmenim benim için büyük bir ilham } \\
\text { kaynağıdır. }\end{array}$ & 1 & 2 & 3 & 4 & 5 & 6 \\
\hline 67. İngilizcemi mümkün olduğunca ilerletmeyi planlıyorum. & 1 & 2 & 3 & 4 & 5 & 6 \\
\hline $\begin{array}{l}\text { 68. Ana dili İngilizce olan daha fazla kişiyle tanışmak } \\
\text { istiyorum. }\end{array}$ & 1 & 2 & 3 & 4 & 5 & 6 \\
\hline $\begin{array}{l}\text { 69. İngilizce öğrenmek önemlidir; çünkü böylece İngilizce } \\
\text { konuşan insanlar ile daha kolay etkileşim içinde } \\
\text { olabileceğim. }\end{array}$ & 1 & 2 & 3 & 4 & 5 & 6 \\
\hline 70. Mümkün olduğunca iyi İngilizce öğrenmek istiyorum. & 1 & 2 & 3 & 4 & 5 & 6 \\
\hline 71. Dürüst olmak gerekirse, İngilizce dersimi sevmiyorum. & 1 & 2 & 3 & 4 & 5 & 6 \\
\hline $\begin{array}{l}\text { 72. Sınıf dışında herhangi bir yerde İngilizce konuşmak beni } \\
\text { rahatsız eder. }\end{array}$ & 1 & 2 & 3 & 4 & 5 & 6 \\
\hline 73. Çoğu yabancı dil kulağa kaba ve sert gelir. & 1 & 2 & 3 & 4 & 5 & 6 \\
\hline 74. İngilizce öğrenmek için gerçekten çok çalışıyorum. & 1 & 2 & 3 & 4 & 5 & 6 \\
\hline 75. Başka bir İngilizce öğretmenim olmasını tercih ederim. & 1 & 2 & 3 & 4 & 5 & 6 \\
\hline $\begin{array}{l}\text { 76. Benim için İngilizce öğrenmek önemlidir, çünkü insanlar } \\
\text { İngilizce bilirsem bana daha çok saygı duyacaklar. }\end{array}$ & 1 & 2 & 3 & 4 & 5 & 6 \\
\hline $\begin{array}{l}\text { 77. İngilizce dersimde konuşurken kendimi gergin } \\
\text { hissediyorum. }\end{array}$ & 1 & 2 & 3 & 4 & 5 & 6 \\
\hline $\begin{array}{l}\text { 78. Dürüst olmak gerekirse, İngilizce öğrenmek için gerçekten } \\
\text { hiçbir istek duymuyorum. }\end{array}$ & 1 & 2 & 3 & 4 & 5 & 6 \\
\hline 79. Bence İngilizce öğrenmek sıkıcıdır. & 1 & 2 & 3 & 4 & 5 & 6 \\
\hline $\begin{array}{l}\text { 80. Hem Türkçe hem de İngilizce konuşan insanların olduğu } \\
\text { bir yerde İngilizce konuşurken kendimi rahat hissederim. }\end{array}$ & 1 & 2 & 3 & 4 & 5 & 6 \\
\hline 81. İngilizce derslerini sabırsızlıkla bekliyorum. & 1 & 2 & 3 & 4 & 5 & 6 \\
\hline $\begin{array}{l}\text { 82. Yabancı dil konuşan insanlarla bir araya gelmekten mutlu } \\
\text { oluyorum. }\end{array}$ & 1 & 2 & 3 & 4 & 5 & 6 \\
\hline $\begin{array}{l}\text { 83. Ailem, İngilizcemi mümkün olduğunca geliştirmem için } \\
\text { beni teşvik ediyor. }\end{array}$ & 1 & 2 & 3 & 4 & 5 & 6 \\
\hline $\begin{array}{l}\text { 84. İngilizcenin daha karmaşı olan yönlerini anlamaya } \\
\text { çalışmaktan sıkılmıyorum. }\end{array}$ & 1 & 2 & 3 & 4 & 5 & 6 \\
\hline $\begin{array}{l}\text { 85. İngilizce derslerinde heyecanlandıklarını söyleyen } \\
\text { ögrenciler sadece bahane buluyor. }\end{array}$ & 1 & 2 & 3 & 4 & 5 & 6 \\
\hline 86. İngilizce öğretmenimi gerçekten seviyorum. & 1 & 2 & 3 & 4 & 5 & 6 \\
\hline
\end{tabular}




\begin{tabular}{|c|c|c|c|c|c|c|}
\hline 87. İngilizce öğrenmeyi çok seviyorum. & 1 & 2 & 3 & 4 & 5 & 6 \\
\hline $\begin{array}{l}\text { 88. Ana dili İngilizce olan kişileri tanıdıkça onları daha çok } \\
\text { seviyorum. }\end{array}$ & 1 & 2 & 3 & 4 & 5 & 6 \\
\hline 89. Keşke İngilizceyi akıcı bir şekilde konuşabilsem. & 1 & 2 & 3 & 4 & 5 & 6 \\
\hline $\begin{array}{l}\text { 90. İngilizce dersi hakkında olumlu bir şeyler düşünmek } \\
\text { benim için çok zordur. }\end{array}$ & 1 & 2 & 3 & 4 & 5 & 6 \\
\hline $\begin{array}{l}\text { 91. Birisi bana İngilizce bir şey sorduğunda kendimi gergin } \\
\text { hissederim. }\end{array}$ & 1 & 2 & 3 & 4 & 5 & 6 \\
\hline $\begin{array}{l}\text { 92. Kendi dilinde altyazılı bir film yerine dilimize dublajı } \\
\text { yapılmış bir TV programını izlemeyi tercih ederim. }\end{array}$ & 1 & 2 & 3 & 4 & 5 & 6 \\
\hline $\begin{array}{l}\text { 93. İngilizce çalışırken dikkatimi dağıtan şeyleri göz ardı eder } \\
\text { ve ödevime odaklanırım. }\end{array}$ & 1 & 2 & 3 & 4 & 5 & 6 \\
\hline $\begin{array}{l}\text { 94. İngilizce öğretmenim, ders materyallerini ilgi çekici bir } \\
\text { şekilde sunmaz. }\end{array}$ & 1 & 2 & 3 & 4 & 5 & 6 \\
\hline $\begin{array}{l}\text { 95. İngilizce konuşstuğumda sınıftaki diğer öğrencilerin bana } \\
\text { güleceğini düşünerek kendimi gergin hissederim. }\end{array}$ & 1 & 2 & 3 & 4 & 5 & 6 \\
\hline $\begin{array}{l}\text { 96. İngilizcenin temel bilgilerinden daha fazlasını öğrenmek } \\
\text { için büyük bir istek duymuyorum. }\end{array}$ & 1 & 2 & 3 & 4 & 5 & 6 \\
\hline $\begin{array}{l}\text { 97. Okul bittiğinde İngilizce öğrenmeyi bırakacağım çünkü } \\
\text { yabancı dile ilgi duymuyorum. }\end{array}$ & 1 & 2 & 3 & 4 & 5 & 6 \\
\hline $\begin{array}{l}\text { 98. İngilizcemi kullanarak yemek siparişi vermem gerekse } \\
\text { sakin olur ve kendime güvenirim. }\end{array}$ & 1 & 2 & 3 & 4 & 5 & 6 \\
\hline 99. İngilizce en sevdiğim derslerden birisidir. & 1 & 2 & 3 & 4 & 5 & 6 \\
\hline $\begin{array}{l}\text { 100.Ailem, İngilizce çalışmaya daha fazla zaman ayırmam } \\
\text { gerektiğini düşünüyor. }\end{array}$ & 1 & 2 & 3 & 4 & 5 & 6 \\
\hline 101.Ana dili İngilizce olan kişilere her zaman güvenebilirsiniz. & 1 & 2 & 3 & 4 & 5 & 6 \\
\hline
\end{tabular}

\section{İkinci dil ediniminin sosyo-eğitimsel modeli'nin Türkiye'de yükseköğretim kurumlarında İngilizcenin yabancı dil olarak öğretilmesi konusunda yeniden değerlendirilmesi}

\section{$\ddot{\mathbf{O} z}$}

Bu çalışmanın amacı, lisans düzeyindeki Türk öğrencilerin İngilizce'yi Yabancı Dil Olarak Öğrenme (EFL) konusundaki çeşitli sosyo-psikolojik yönelimlerini kapsamlı bir genel bakışa sahip olacak şekilde incelemektir. Çalı̧̧ma öncelikle okul yönetimi tarafından İngilizce öğretimin kalitesinin geliştirmesi ve bu konuda öğrencilerin dil öğrenme motivasyonları ve İngilizce öğrenmeye yönelik tutumları açısından bireysel farklılıklarının anlaşılarak daha olumlu tutumlar geliştirilebilmesi için tasarlanmıştır. Çalışmaya katılan 793 öğrenci Türkiye'deki bir devlet üniversitesinde alan eğitimlerini İngilizce olarak tamamlayabilmek amacıyla üniversite tarafından sunulan bir yıllık yoğun hazırlık sınıfı eğitimi almaktaydılar. Veriler, Tutum-Motivasyon Ölçeği (AMTB) (adapte edilmiş Türkçe versiyon, Gardner, 2004) kullanılarak toplanmıştır. AMTB tarafindan ölçülen 6 yapıya (entegrasyon, öğrenme durumlarına yönelik tutumlar, motivasyon, dil kaygısı, araçsal yönelim ve ebeveyn teşvik düzeyleri) 
ilişkin toplanan veriler İngilizceyi Türkiye'de yabanc1 dil olarak öğrenen yükseköğretim öğrencilerinin cinsiyetlerine ve İngilizce yeterlilik düzeylerine göre mevcut durumu gösterebilmek için SPSS 23 yazılımı kullanılarak analiz edilmiştir. Bu çalışmanın sonuçları, yükseköğretim düzeyinde İngilizce öğrenen Türk öğrencilerinin, İngilizce konuşan insanlara yönelik tutumları ve dil öğrenme kaygıları dışında, AMTB yapıları ve alt ölçekleri tarafından ölçülen niteliklerinin nispeten yüksek düzeyde olduğunu ortaya koymuştur. İlginç bir bulgu olarak, araştırmaya katılan öğrencilerin İngilizce derslerine katılma ve İngilizce kullanma konusunda sık sık endişeli oldukları görülürken, kız öğrencilerin erkek öğrencilere kıyasla bu konularla ilgili daha fazla rahatsılılk duydukları saptanmıştır.

Anahtar sözcükler: İngilizceyi yabancı dil olarak öğrenmeye yönelik tutumlar; İngilizceyi yabancı dil olarak öğrenme motivasyonu; Hazırlık okullarında İngilizce öğretimi; Türk tutum/motivasyon ölçeği;Türkiye'de İngilizcenin yabancı dil olarak öğretilmesi

\section{AUTHORS BIODATA}

Seden Eraldemir Tuyan is a lecturer doctor in ELT Department at Çağ University, Mersin. She is teaching methodology courses at undergraduate and graduate levels. Her major interests are Emotional Intelligence, SocialEmotional Learning, individual differences in SLA, Action Research, personal and professional development.

Prof. Dr. Ergün Serindağ is currently the Head of School of Foreign Languages at Çukurova University, Adana. Between the years 1981-1990, after studying Informatics Mathematics at the University of Frankfurt, he received his second BA degree in German Language Education Department at Çukurova University in 1993. He also received his MA and Ph.D. degrees at Çukurova University. His research areas are linguistics and foreign language education. He has a good command of German and English. 